Kennesaw State University

DigitalCommons@Kennesaw State University

Faculty Publications

6-2004

\title{
Course Revitalization as a Change Driver Throughout Undergraduate Business Curriculum
}

Elke M. Leeds

Kennesaw State University, eleeds@kennesaw.edu

Radwan Ali

Kennesaw State University, rali@kennesaw.edu

Follow this and additional works at: http://digitalcommons.kennesaw.edu/facpubs

Part of the Curriculum and Instruction Commons, Educational Assessment, Evaluation, and $\underline{\text { Research Commons, Higher Education and Teaching Commons, and the Other Education }}$ Commons

\section{Recommended Citation}

Leeds, E., Ali,R. "Course Revitalization as A Change Driver Throughout Undergraduate Business Curriculum." Journal of College Teaching \& Learning (TLC) 1.6, 2004.

This Article is brought to you for free and open access by DigitalCommons@Kennesaw State University. It has been accepted for inclusion in Faculty Publications by an authorized administrator of DigitalCommons@Kennesaw State University. For more information, please contact 


\title{
Course Revitalization As A Change Driver Throughout Undergraduate Business Curriculum
}

Elke M. Leeds, (E-mail: Elke_Leeds@coles2.Kennesaw.edu), Kennesaw State University Radwan Ali, Kennesaw State University

\begin{abstract}
This paper describes the revitalization of Business Information Systems and Communication, a high enrollment, prerequisite course for all undergraduate business students in the Coles College of Business. An overview of the course components is presented and original structure described. The rationale for change, technologies leveraged and measures of success are presented. The change drivers are identified and their impact on undergraduate curriculum delineated. Lessons learned and future implications are discussed.
\end{abstract}

\section{Introduction}

ennesaw State University (KSU), the Coles College of Business and the Business Information
Systems Management concentration have faced some unique challenges while addressing course
design, constrained resources and learning goals. Two primary undergraduate skill development core offerings, Business Communications and Introductory Information Systems, were previously collapsed into a single course with the accompanied name change of E-Business (EBIZ). With an average enrollment of over 100 students per section, limited computer lab resources and increased expectations of downstream faculty and accreditation reviewers, course revitalization was imperative.

A semi-annual course review began the revitalization initiative with an examination of each learning objective and course component. A revised, web-based offering was created to introduce web-based technologies and exploit the interrelatedness of communication skills and the electronic environment. Initial design focused on the challenge of converting large lecture audiences to interactive classroom participants. Successes were realized and contributing factors were isolated through course reviews and solicited feedback. The first iteration focused on the use of technology, expansion of electronic classroom facilities and an integrated undergraduate curriculum. The change drivers in the course structure were delineated, revised and improved to align themselves with accreditation warranted assurance of learning goals. The course continues to be improved and modified on a continuous improvement philosophy. Details of the course review, redesign, launch, measurements, isolated change drivers, review cycles and future directions are provided.

\section{Course Review As Change Driver}

EBIZ 2100, Business Information Systems and Communications was a course beleaguered by overwhelming learning objectives (Appendix A), a wide variety of non-related components and several different text resources. Course prefix was questioned as EBIZ insinuates a primary focus on Web design and e-commerce. While this is a component, BISM, business information systems management incorporates the Web and e-commerce components within the management context. The revitalization initiative aimed to coordinate learning goals into a building block semester long project, integrating all required components and leveraging Internet technologies to foster exposure to online learning environments and technology skills. Each objective was reviewed, tested for learning requirement and melded together to reflect a project experience with increased rigors. 


\section{Course Objectives As Change Drivers}

The original course objectives were presented as three separate mini courses with minimal connectivity among components. They were overly specific, disallowed for variation in application of skills, and did not leverage available technology. The objectives listed did not accommodate the reality of a large enrollment class that includes significant variations of skills among the students. A new approach was needed, so the original objectives were redesigned to meet the emerging needs. A justification for the revitalization was delineated as part of the annual course review and proposal for course change. Course prefix was changed from EBIZ 2100 to BISM 2100, Business Information Systems Management. Highlights are shown in Appendix B.

The revised course objectives include: (1) improvement of business communication skills through business letter, memos, reports, and presentations, (2) increase proficiency in students use of business applications software, and (3) introduction of information technology concepts and skills essential to conducting business in electronic environments. These objectives were designed to create a solid connection between the core undergraduate business curriculum and information technology. The rationale shown in Appendix B is based on established Cole College of Business Undergraduate Learning Goals. An exercise as a precursor to accreditation review was conducted to evaluate the effectiveness of the rationale and the correlation to published goals. It is shown in Appendix C.

To achieve the course's learning goals and accelerated learning demands, various student assignments were adopted. For example, an Excel individual project was introduced to ensure that students become efficient at using a spreadsheet application to solve business problems. The Excel project required the students to provide a business plan for a small business. The business plan required a creation of Cash Pro-Forma budget that included calculation of costs, revenues, loan payment, taxes, monthly, and annual totals. The individual project also required the students to create charts and provide recommendations for the business. Another example is a semester long group project. The project was created to combine the three broad course objectives into an interrelated project and presentation that built on individual course components and highlighted the interrelatedness of the topics. Students are asked to investigate a particular software or application and perform an in-depth analysis on its use, functionality, benefits, cost and impact on the relevant business function. The project topic is individualized and challenges a group of students to investigate software in their intended field of study and to integrate their writing, organizational, presentation, research, and information technology skills. In their respective sections of the course, faculty deliver component modules according to individual preference, however the end result is a common course deliverable.

The information technology aspect of the redesigned course intended to address and satisfy the new demand for technology skills among business school undergraduate students. That aspect includes two components: business office and application skills and Internet technology skills. Business office skills included oral, written communication, and presentation skills in addition to using various software applications to enhance the communication and presentation skills. The Internet technology skills cover World Wide Web (WWW) navigation and publishing skills, electronic mail, evaluating the validity of Web resources, and the use of a course management system (CMS). The CMS used in this course is WebCT.

WebCT is a Web-based CMS used as an electronic medium and supplement for the face-to-face class meeting. Learning material including lecture notes, presentations, course assignments, student gradebook, and other relevant course material are uploaded to the WebCT supplement for better student access.

\section{The Rationale And Model Behind The Revitalization Process}

To prepare for the revitalization process, the authors thought it would be appropriate to adopt an implementation model, based on the Deming Wheel from Out of the Crisis, and the Plan-Do-Check-Act cycle. The model, referred to as the Continuous Improvement Wheel (CIW) (Figure 1) depicts the phases of examination, trial, measurement of success, inclusion or rework/improvement, and training. 
Figure 1 - Continuous Improvement Wheel (CIW) Model

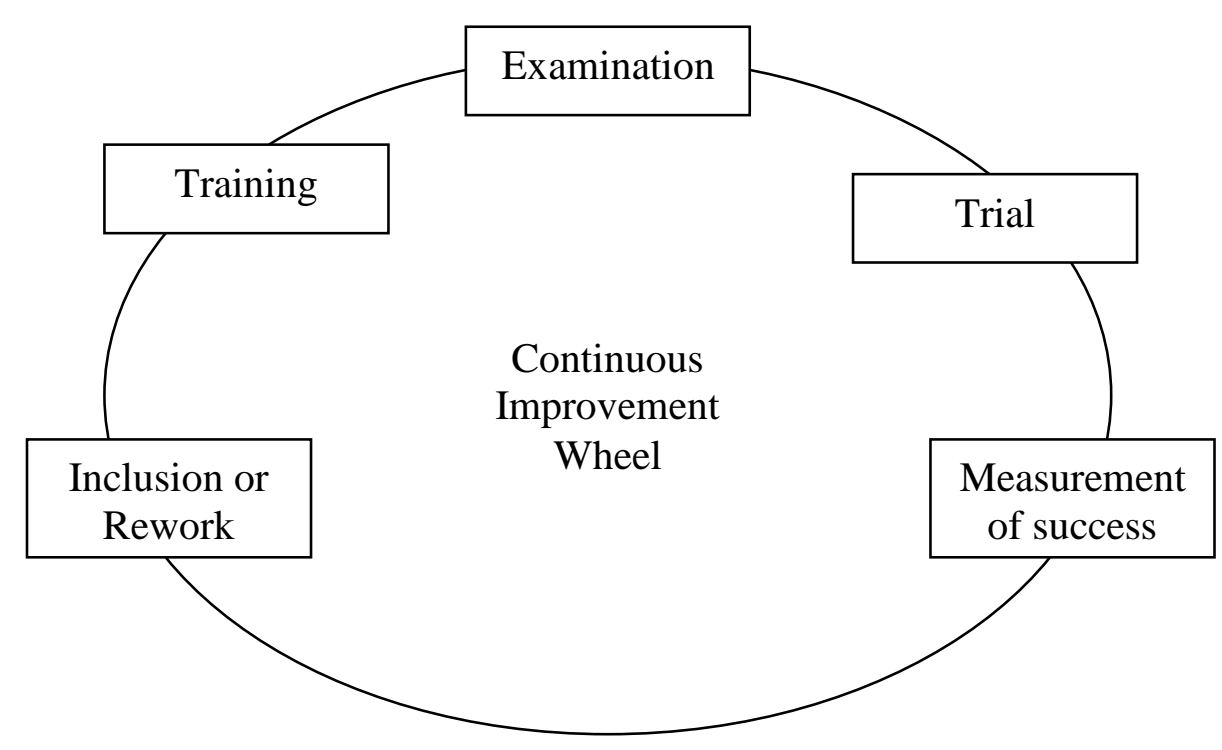

The first step in the BISM 2100 course revitalization process was the examination of the very first learning goals. These goals were adopted based on a decision science course approach. They were outdated because information technology had made huge jumps to modernity. New learning objectives were created, and needed to be tried.

The trial phase of the CIW model covered implementing and testing the new learning objectives. For example, one of the objectives was training the learners on business presentation skills and software application. A business communications textbook that includes lectures about business presentations was assessed and selected for the course. In addition, Microsoft PowerPoint was introduced as a standard business presentation tool to help students create a business presentation as one of the course's individual assignments. The trial phase needed benchmarks and measurement of success.

The measurement of success phase included implementing an assessment approach to measure students' performance and to solicit developmental feedback. For example, as an assessment for the presentation assignment described in the previous paragraph, a group project with a presentation component was used in the BISM 2100 course. In their respective groups, the students were required to deliver a PowerPoint presentation before the rest of their classmates. The presentation component was used as a further assessment of what every student had previously submitted on his/her own and as a pre and post test measure. Another way to measure was using feedback from faculty who require some of the skills taught in BISM 2100 in their respective courses. An informal colloquium has been established to review skill proficiency by downstream faculty. For example, many of the students who take the BISM 2100 course are accounting majors who will need spreadsheet skills to work there accounting homework. Methods are being instituted to measure the declining need to re-teach pre-requisite skills.

Upon the students' performance with their groups and faculty feedback, the BISM 2100 course's objectives might need to be reworked or improved. The CIW model accommodates the rework/improvement phase. The goal of this phase is to improve all components to serve the learning objectives of the course more effectively. The ultimate goal is the inclusion-- of what we believed were -- vital components.

The inclusion phase of the CIW model deals with deciding whether an adopted BISM 2100's component (learning goals, assignments, tools, etc.) was providing an effective learning experience for the students. A training 
component has been added to bring adjunct faculty up to date on course improvements to ensure a common post completion skill set. In some cases, this happens between semesters. The authors felt that he CIW model was needed as a guideline in the revitalization process of BISM 2100. The model is new and will be improved to a more stable framework for future development.

\section{Results Of The Revitalization Process}

The revitalization process produced many positive results that demonstrated the importance of the BISM 2100 course. These results include changes in the business undergraduate curriculum, additional electronic classroom, and increased offerings in technology training workshops.

\section{Ms Excel In The Curriculum}

The original three mini-courses were assessed and redesigned upon feedback from various sources. BISM 2100's faculty driven increase in application rigor prompted departmental response. An Ad Hoc Excel in the Curriculum committee was formed to investigate the current use of Excel by faculty. The committee established a minimum specification for capabilities and mapped the skills to the appropriate course offering (Appendix D). Validation of skill balance was received when undergraduate BBA accounting faculty met with representatives from the Atlanta firm of William, Benator and Libby in September 2002. Representatives indicated that MS Excel proficiency was strongly desired yet often missing in the new hire skill set. Skills were cross-referenced and adopted as departmental course requirements. Workplace requirement was reinforced through the inclusion of MS Excel skill testing for new hires. An example of a recruiter's skill test is shown in Appendix E. Results from the BBA Accounting Excel in the curriculum committee are currently filtering through the Coles College BBA common core course degree requirements to examine fit and appropriateness for a lock stepped curriculum and technology skill implementation.

\section{Required Course For All BBA Programs}

The business undergraduate curriculum was modified to reflect the importance of the BISM 2100 course as a basis for later courses, and consequently, future employment. The BISM 2100 course is required for all business majors to move to higher level (3000 or 4000) courses. The course became a requirement to meet the demands of the upper level courses. Some of these courses, for example accounting, require students to have spreadsheet skills. There were no courses that provided these skills, so the accounting faculty would take class time from accounting lectures to teach spreadsheet application such as Lotus or Excel. The requirement showed the administration's commitment to technology, along with an approval for an electronic classroom large enough to accommodate the large enrollment of BISM 2100.

\section{Commitment Of Resources}

Currently, KSU does not have an electronic classroom that will accommodate 100+ students in one setting. Any time an electronic classroom was needed, the students of one section of the course, would be divided into three different rooms of 40 personal computers each. The instructor had to move from one room to another to introduce a new skill or answer questions. Considering the tight budgets and resource limitations, the administration implemented a BISM student fee to create a revenue stream to support the technology initiative. In this instance, resource limitations acted as creativity boosters and change drivers. The technology initiative was not limited to the electronic classroom. The administration commitment also showed in support to increase in technology training for faculty.

Three different departments at KSU provide technology workshops for faculty, staff, and students. These departments are Instructional Technology (IT), Presentation Technology Department (PTD), and Information Technology Services (ITS). IT is specialized in WebCT offerings, PTD in graphics applications, and ITS in Microsoft products such as Windows and Office. Each of the three departments noted an increase in the number of new course offerings as students and faculty are becoming more aware of training availability through course 
exposure. The significance in the rigors of these offerings is shown by the increase of the number of specialized workshops. The presentation technology department increased the number of specialized courses by $20 \%$ over 20022003 offerings focusing more on advanced, higher-level skill sets. Additionally, the number of faculty requesting WebCT training is increasing continuously as student exposure and skills increase and cause pressure for on-line course technology.

\section{Impact On Other Courses}

A higher-level technology course, similar in content to BISM 2100 is taught at the Computer ScienceInformation Systems (CSIS) department at KSU. The course is Information Technology (IT) 3700, a junior level course that acted as a support course for the college of business before the BISM concentration manifested. IT 3700, in its current form, has similar student assignments such as Access, Excel, PowerPoint, and Word and covers similar topical areas such as Internet technology and security. The component that differs is the business communication aspect; BISM 2100 has it, but IT 3700 does not. Currently, the BISM faculty is meeting with the CSIS faculty who teach IT 3700 to modify the course to avoid repetition of material and increase course rigors as skill levels increase. The revitalization of BISM 2100 creates an opportunity for the modification of this course and the positive impact of natural creative tensions that exists in dual departmental processes. The inclusion of new management information system modules and project management theories are layered in positive cross-departmental collaboration and increased educational opportunities.

\section{Impact On Program Requirements}

Another change whose origin can be traced in part to course revitalization efforts was a grade point average (GPA) sophomore requirement. Before a business major can enroll in any upper-division business courses (30004000), she or he must earn an adjusted GPA of 2.70 or greater in a set of seven courses that include mathematics, accounting, and BISM 2100, in addition to other subjects such as economics and business law. The sophomore GPA requirement increased from 3.70 to 3.875 and established a technology and communications gate. No grade lower than a "C" can be received in any one of the courses. The GPA increase goes into effect August 1, 2004. If the student had taken the courses at KSU or at another accredited institution, the grades earned will be used to check this GPA requirement. A course may be repeated if necessary. The purpose of the requirement is to raise the level of student performance and to ensure technological and communications competence before progressing into the junior and senior years.

\section{Ongoing Changes And Improvements}

Course revitalization is not static. The process of revitalizing BISM 2100 and measuring its impact on downstream courses, student learning and program development is on-going. Innovative student projects and capital resource allocations are currently being proposed, reviewed and tested for future inclusion. A description of current projects and their anticipated impact is presented below:

- $\quad$ Resource Allocation - The BISM faculty team has proposed a 120 -seat electronic classroom and presentation lab to benefit BISM 2100 students. Details of the proposal and its anticipated returns are outlined in Appendix F. The faculty team received approval for the classroom conversion, is currently working with vendors and the University's Information Officer. Project completion is anticipated for Fall 2004.

- $\quad$ Presentations Outsourced To Digital Video - The semester long group project with in-class presentation has been converted to a video presentation project. Students are now exposed to presentation technology, digital media, film editing and video file manipulation. Three class periods of presentations have been replaced with one period of presentation technology training. This frees up two additional classes for higher-level content investigation and new course materials, consistent with the goal of increased course rigors. This also provides for pre and post-testing of business presentation and communication skills as students are submitting evidentiary skill proficiency in video files. The tie-in to assurance of learning will be explored as downstream courses are introduced to the video presentation model. This project is currently 
being utilized in two 100-student sections and pending feedback and review, will be fully incorporated in Spring 2004.

- $\quad$ Service-Learning Initiative - Learn and Serve is an experiential instructional methodology that reinforces the academic objectives of a course through meaningful and thoughtfully organized community service. It builds and reinforces curriculum-based academic knowledge while meeting community needs and/or promoting public good. It provides an excellent academic process to motivate and measure a student's involvement and mastery of technological and communication tools. Additionally it provides an ideal opportunity for formal and informal measurement of a students' ability to apply complex subject matter. Students are introduced to Cobb Micro Enterprise Clients and act as Pro Forma Cash Budget consultants. Student training occurs through the completion of the Pro-Forma MS Excel business case. The initiative is currently being tested in two 100-student sections and exposes students to a professional business environment, fosters a sense of community responsibility and ties in to the Coles College assurance of learning goals. A learn and serve survey has been added to the WebCT course platform and will assess the student experience in terms of assurance of learning goals depicted in Appendix C.

- $\quad$ On-Line Offering - One of the main proposed future changes to BISM will be a fully online offering. The plan for online class will include posting lecture notes, presentation, audio and video recordings. In addition the course will use a student discussion forum, and Web logs (blogs) or journal postings. The assignments and grades will be exchanged electronically through WebCT links. For the final group project -- that currently requires an in-class presentation and a written a report-- a digital video presentation will be submitted. Only three face-to-face meetings will take place: The first day of class to introduce the course, and two other meetings for the midterm and final exams. A few careful steps will take place in Spring and Summer 2004 semesters, but the full plan is set for the Fall 2004 semester.

- $\quad$ Course Learning Architecture - To capture the proposed benefits of fully on-line courses, the faculty team will be researching the application of a learning architecture to one 600+ enrollment student section of BISM 2100. Faculty roles will be established according to knowledge management principles. Keepers of knowledge resources, students and technology will be identified to investigate the creation of a one section, team-taught course.

- $\quad$ BBA in BISM - As the BISM course continues to be revitalized and impacts undergraduate business curriculum, new courses are being offered as "special topics" to test the receptivity of an undergraduate degree in Business Information Systems Management. A concentration is currently in place and benefiting from new course development. More study is needed to determine the appropriateness of a separate degree program and the learning goals associated with this area of study.

\section{Conclusion}

The revitalization of BISM 2100 in the Coles College of Business set in motion a series of changes and improvements that ultimately impacted undergraduate business curriculum, undergraduate GPA requirements and technological resource allocation. The rationale for change was based on an annual review process, coupled with faculty identification of outdated objectives, as related to student, recruiter and user experience. A series of improvements were identified, tested and reviewed for inclusion based on a continuous improvement cycle. Successes were realized and future improvements are continually being tested and instituted. Long terms course development plans have been established and will be investigated while simultaneously pursuing an undergraduate degree program in Business Information Systems Management.

\section{References}

1. Deming, W. Edwards. Out of the Crisis. Cambridge, Mass.: MIT Center for Advanced Engineering Study, 1982.

2. $\quad$ Ellsworth, J.B. (2000). "Surviving change: A survey of educational change models." Syracuse,

NY: ERIC Clearinghouse on Information and Technology. (ED 443 417)

3. $\quad$ Rosenberg, Marc. (2001). E-learning. New York: McGraw-Hill.

4. Intentional Change By Design. By: Shinn, Gregory S.. Quality Progress, May2001, Vol. 34 Issue 5, p46, 6p, 2 diagrams, 1c; (AN 4775924) 
Appendix A Course Objectives From EBIZ 2100 Prior to Revitalization - Fall 2002

\begin{tabular}{|l|}
\hline EBIZ 2100 Course Objectives \\
\hline General Objectives - By the end of this course, the student will be able to discuss and give examples of the following: \\
\hline How businesses and not-for-profit organizations help create our standard of living. \\
\hline Social, demographic, and global trends that affect businesses today. \\
\hline How technology is changing business today. \\
\hline Types of economic systems that exist in the world today. \\
\hline How small businesses contribute to the US economy. \\
\hline Why people start their own businesses. \\
\hline What characterizes a successful entrepreneur? \\
\hline What are the risks and rewards of owning one's own business? \\
\hline Steps to take in starting a small business. \\
\hline Where to get help in starting a small business. \\
\hline $\begin{array}{l}\text { Communication Skill Objectives - By the end of this course, the student will be able to discuss and give examples of the } \\
\text { following: }\end{array}$ \\
\hline
\end{tabular}

Explain the importance to a written communication or oral presentation of 1) defining your purpose, 2) analyzing your audience, and 3) establishing a logical ordering of the content.

Identify examples of and use appropriately, the following seven logical orderings of the content in a written work or oral presentation: priority; reverse priority; chronological; reverse chronological; comparison; contrast; and spatial.

Apply, and identify deviations from, the standard formats for a memo and a letter.

List, describe, and apply the "seven C's" of effective business writing: completeness, clearness; concreteness; correctness; conciseness; courtesy; and character.

Employ active writing, and change passive writing to active writing.

Incorporate, within a formal report: three levels of headings; paragraphs each having a topic sentence and all remaining sentences related to that topic sentence; transitions between major divisions; proper attribution for the words and ideas of others; proper placement, labeling, and referencing of figures and tables; and an acceptable (e.g., APA, MLA) system of referencing.

Identify deficiencies related to the items addressed in the objective above

Describe a plan for a collaborative writing project.

List and describe the "three P's" of oral presentations: preparation; practice; and presentation.

Prepare an outline for an oral presentation: the introduction (with an attention getter, statement of purpose, and preview of main points); the body (with a minimum of three sections, each containing a main point and a minimum of two supporting details); and the conclusion (with a review of the purpose, a review of the main points, and a closer).

Create presentation software slides exhibiting the following characteristics: at most several lines of text and at most several words per line for each slide; consistent appearance (e.g., background, margins); no clutter; simple typeface; and judicious (e.g., limited, not distracting) use of color.

Recognize in an oral presentation the absence of any of the following eight behaviors associated with a professional delivery style: clear and confident voice; conversational tone; no reading; eye contact; upright posture; no nervous mannerisms; loud enough for all to hear; and within time limit.

\section{IT Skill Objectives - By the end of this course, the student will be able to:}

\section{Using Word 2000:}

1. Create, modify, and delete footnotes and endnotes.

2. Create form letters and mailing labels.

3. After running the Spell and Grammar Checker, request and review readability statistics.

\section{Using Excel 2000:}

4. Create customized charts using such advanced formatting features as inserting comments and highlighting chart features.

5. Apply advanced Excel functions (e.g., IF, COUNTIF, HLOOKUP).

6. Create a text box and drop-down list box.

7. Insert Comments.

8. Create a simple macro.

9. Copy, move and reference data between and across worksheets in a workbook.

10. Work with lists using filters to extract subsets and using pivot tables to summarize and reorganize data.

Using PowerPoint 2000:

11. Apply special effects (e.g., sound, animation) to slides.

12. Create an organizational chart reflecting given reporting relationships.

For Word 2000, Excel 2000, and PowerPoint 2000: 


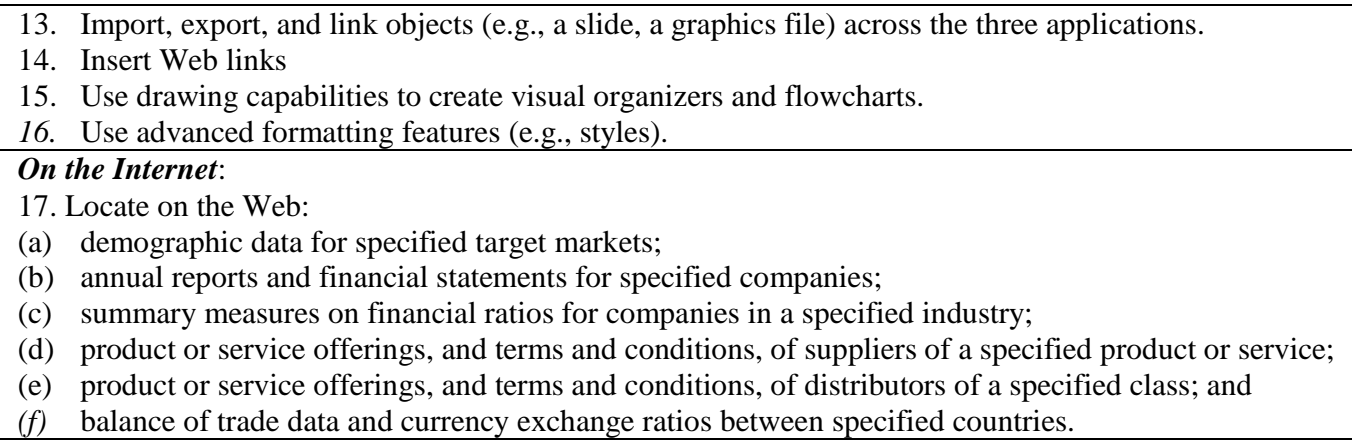

\section{IT Concept Objectives - By the end of this course, the student will be able to do the following:}

1. Provide and recognize definitions of the following information technologies:
(a) TCP/IP
(f) intranet
(b) HTML
(g) extranet

(c) HTTP

(h) DSL

(d) Internet telephony

(i) ISDN

(e) applet

(j) .gif, .jpg, and .pdf files

2. Identify and describe the role of each of the following in electronic security:
(a) firewalls
(d) virus protection
(b) SSL
(e) user ID and password

(c) encryption

3. Identify and describe the following areas of vulnerability within electronic environments:
(a) viruses
(c) data integrity
(b) hackers
(d) privacy

4. Recognize and provide examples of how information technology is used to:

(a) automate (perform structured tasks that would otherwise be performed by people) ;

(b) informate (provide information to people);

(c) embed (control or monitor processes by being embedded in systems or organizations); and

(d) transform (greatly change the structural relationships within an organization, industry, or economy).

5. Differentiate between the following generic varieties of information systems, and both recognize and provide examples of each:

(a) Transaction Processing Systems

(b) Information reporting systems (EIS, MIS)

(e)Office Automation systems

(c) Decision Support Systems (DSS)

6. Describe the Internet business models articulated by Michael Rappa of North Carolina State University, and for each model both recognize and provide examples of companies that have adopted that model (either singly, or in concert with one or more other models).

7. List and describe the eight critical success factors, as articulated by Geoffrey E. Bock and David S. Marshak in "A Guide to Succeeding in the Net Economy," for successful strategic e-commerce initiatives.

8. List, describe, and recognize the major marketing/sales, content, and technology roles in e-commerce as articulated by Geoffrey E. Bock and David S. Marshak in "A Guide to Succeeding in the Net Economy."

9. Describe an instance (with respect to a specific company) in which information technology played a major role in:

10. Describe ethical issues related to privacy, accuracy, property rights, and access.

\section{Appendix B Justification and Process of Revitalization of Course Objectives}

\section{BISM 2100 Course Review}

Briefly describe any weakness of existing course goals/objectives.

- Objectives overly specific and disallow variations in application of skills

- Objectives not geared to reality of class environment and large class sizes

- Objectives do not address variance of incoming student skill

- Objectives limiting flexibility of environmental changes and updates

- Objectives do not integrate to provide a systems overview

- Do not address systems use across functional areas of business

- Objectives listed did not address application and purpose for skills acquired 
A review of the goals and objectives, consequent evaluation of weaknesses, supports strategic change to goals/objectives as part of course revitalization:

Strategic changes to goals/objectives:

- Significantly adjust the number of stated objectives

- Broaden the stated objectives to encompass a wider variety of interrelated business skills - emphasizing the functional areas of business

\section{Published changes to goals/objectives:}

- To provide business undergraduate students with foundational systems knowledge, in an integrated manner, which will enhance successful completion of Upper Division Business Core Classes.

- To provide students who are new to, or have been out of the technological arena for a significant time with a refresher in basic MS Office skills and knowledge.

- To establish a new rigor in systems use by intensive training in system skills focusing on the integration and compatibility of the most commonly used systems

- To prepare students to maximize their probability of effective learning as they enter core classes and learning experiences in their declared major or chosen area of specialization.

- To provide students with a common foundation in the "language of business" and the tools to communicate effectively in the language and appropriate mode of delivery.

- To help students interpret the systems used in the various business disciplines and to demonstrate comprehension and effective use of these functional systems in problem solving, decision making, and business research.

- To develop team skills for sharing information and experiences, problem solving, and project work in faceto-face and virtual team settings.

- Objectives for each learning module are presented in the weekly syllabus

The revision of stated goals and objectives prompted a subsequent review of course materials, relevance of topics covered, the interrelatedness of topics covered, and their applicability to today's business environment.

It was concluded that while the change to specific objectives better-delineated Coles College of Business course objectives, changes needed to be made to update the course content and delivery. The following table provides the changes made and the accompanying rationale. 


\begin{tabular}{|c|c|}
\hline Course Change & Rationale \\
\hline Converted to a Web based delivery platform & $\begin{array}{l}\text { A Systems course needs to adopt the latest and most productive } \\
\text { delivery methods and exploited the course delivery platform as an } \\
\text { instructional tool for file management, internet searches and on-line } \\
\text { functionality }\end{array}$ \\
\hline Established course minimum technology requirement & $\begin{array}{l}\text { A technology based course needs to rely on congruent and } \\
\text { compatible versions for consistency in delivery and deliverables. } \\
\text { (On-campus standards set specification) }\end{array}$ \\
\hline $\begin{array}{l}\text { Established minimum skills definition and provided } \\
\text { access to resources to meet expected minimum }\end{array}$ & $\begin{array}{l}\text { Leverage free ITS training available in Coles College for registered } \\
\text { students and incorporated offering into course goals and graded } \\
\text { materials. Also exposed students to availability of resources for free } \\
\text { certificate based training }\end{array}$ \\
\hline $\begin{array}{l}\text { Converted skill demonstrations into interactive skill } \\
\text { workshops }\end{array}$ & $\begin{array}{l}\text { Program skills require hands-on practice and in class repetition. } \\
\text { Wireless laptops were incorporated into the classroom environment }\end{array}$ \\
\hline $\begin{array}{l}\text { Leverage real time data for case examination and } \\
\text { introduction to data mining }\end{array}$ & Focus to include more business environment applicability \\
\hline $\begin{array}{l}\text { Team building, operating agreements, peer review } \\
\text { and incorporated feedback added }\end{array}$ & $\begin{array}{l}\text { Most sophomore level students have not received instruction on } \\
\text { effective team management, time management and meeting } \\
\text { management. This addition sets the standard for subsequent class } \\
\text { group work and culminates in a substantial team project. }\end{array}$ \\
\hline Integrated Assig & $\begin{array}{l}\text { Blending of varied course objectives into a unified projects focus on } \\
\text { the importance of integration and unification of topics }\end{array}$ \\
\hline Capstone Project & $\begin{array}{l}\text { Introduced the rigors of research and the flexibility of topics to align } \\
\text { with the students intended area of study }\end{array}$ \\
\hline Capstone Presentation & $\begin{array}{l}\text { The presentation module of the course mandates an actual graded } \\
\text { presentation. Teams are used and practice times schedule to } \\
\text { accommodate class sizes of } 100+\text { students }\end{array}$ \\
\hline $\begin{array}{l}\text { Proof and Practice Requirement - Peer review of } \\
\text { papers and presentations }\end{array}$ & $\begin{array}{l}\text { Identified the need to establish preparatory habits and high quality } \\
\text { contents through proof and practice exercises }\end{array}$ \\
\hline $\begin{array}{l}\text { Introduction of Systems used across functional areas } \\
\text { for business }\end{array}$ & $\begin{array}{l}\text { Wanted to establish BISM } 2100 \text { as a touchstone course introducing } \\
\text { systems used in Marketing, Accounting, Operations and Logistics, } \\
\text { Finance and Small Business Management. Done as an introduction } \\
\text { to fields of study, ability to adapt a specialize capstone project to } \\
\text { program interests and to establish a foundation for a more integrated } \\
\text { curriculum through the levels of study. }\end{array}$ \\
\hline $\begin{array}{l}\text { Established standard course delivery and content } \\
\text { across all sections offered }\end{array}$ & $\begin{array}{l}\text { For downstream faculty to rely on skills acquired and concepts } \\
\text { covered, and to be able to build upon the defined skills, section need } \\
\text { to be uniform in content and deliverables }\end{array}$ \\
\hline
\end{tabular}

\section{Course title per the current catalog:}

Business Information Systems and Communications

Does the title suit the course? Yes

\section{Course description per the current catalog:}

Business information course to (1) improve communication skills appropriate to the business setting; (2) expand proficiency in the use of business application software; and (3) introduce information technology concepts relevant to doing business in an electronic environment.

Does this description adequately describe the course? Yes

\section{Prerequisites per catalog:}

All developmental studies courses

Do these prerequisites suit the course? Yes

Recommendation for changes to the title, description, or prerequisites: 
Course prefix change requested by proposal to KSU undergraduate curriculum committee EBIZ 2100 change to BISM 2100

Rationale - EBIZ insinuates Web design and e-commerce. While this is a component, BISM, business information systems management incorporates the Web and e-commerce components within the management context. The prefix change also provides consistency with incoming transfer students and aligns with other BISM course offerings

Appendix C: General Learning Objectives and Specific Learning Objectives - Mapped to BISM 2100 - BBA - Coles College

1.0 Critical Thinking

Each student can think critically, identify problems, research and analyze problems and make decisions

1.1. Identify problems and opportunities. (knowledge)

BISM 2100 - students complete an investigative report identifying problems and opportunities for businesses identifying software solutions

1.2 Recognize and apply appropriate research tools and databases to generate alternative solutions.(knowledge \& skill)

BISM 2100 - students conduct building block search on academic database and evaluate validity of Web resources

1.3 Evaluate data in order to compare and contrast alternatives to reach a defensible solution. (skill)

BISM 2100 - students tested on in-class Web resource credibility evaluation exercise

\subsection{Ethics}

Each student can recognize, analyze and choose resolutions to ethical problems explicit or implicit in decisionmaking.

2.1 Recognize the appropriate code of ethics that applies to a discipline in a business situation. (knowledge)

2.2 Analyze and compare resolutions to ethical issues encountered in a business environment. (attitude \& skill)

BISM 2100 - Cyber Ethics debate - in class exercise

\section{$\underline{\text { 3.0 Interaction }}$}

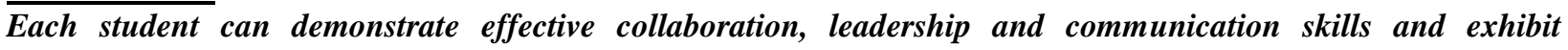
professional behavior.

3.1 Recognize the value of working cooperatively with others. (attitud

BISM 2100 - students tested on team effectiveness and synergy

3.2 Demonstrates the ability to work with others in a professional manner. (skill)

BISM 2100 - students complete and Web publish a team operating agreement with delineated roles and perform a team effectiveness assessment

3.3 Comprehends the skills necessary to influence, inspire and motivate individuals and groups to achieve results. (knowledge)

3.4 Demonstrates the ability to effectively communicate information to individuals with diverse backgrounds.(attitude \& skill)

BISM 2100 - students are tested on effective communication skills through a comprehensive exam on the communication process and written and oral communication

3.5Provides examples of professional organizations, certifications, and other opportunities for professional development. (knowledge) 


\subsection{Technology}

Each student can identify opportunities to leverage technology in decision-making and can use technology for personal productivity

6.1 Identify and operate appropriate computer software for analysis and data presentation. (Knowledge \& skill)

BISM 2100 - MS Word, Excel and Power Point demonstration and practicum are completed in-class. Comprehensive demonstration of skills assessed through ProForma Business Case Application

6.2 Effectively use technology to improve personal productivity. (skill)

BISM 2100 - Students create and publish a webpage for assignment submission and potential employer review Appendix D: Excel in the Curriculum Ad Hoc Committee - Skill Implementation By Course

To: $\quad$ Dr. John McAllister - Chair

Accounting Department

From: Excel in the Curriculum - Skill Implementation By Course

Date: December 15th, 2003

Subject: Committee Results

Please find information detailing the implementation of the Excel in the Curriculum AdHoc Committee's recommendations:

The implementation is based on a review of Excel skills across the curriculum in the Accounting Department. Original committee members interviewed colleagues and sought out information pertaining to skills expected; skills demonstrated, skills taught, skills utilized in courses and skills graded in application deliverables. Results varied widely with some faculty making wide use of Excel based applications and some not currently employing the use of any Excel or spreadsheet related functions. The committee used information gathered and determined that a minimum specification of Excel skills across the curriculum was warranted. Information garnered from faculty members was used as the basis for establishing the minimum specification.

The department voted on and approved the minimum specifications list attached. Minimum Skills List for Implementation.xls

The subsequent table details the forward progression of the minimum skills implementation by faculty by course.

Skills will be identified as:

- $\quad$ (D) - Demonstrated in class or through printed materials

- $\quad(\mathbf{U})$ - Utilized in class or independently

- $\quad$ (G) - Graded as a deliverable

- $\quad(\mathbf{T})$ - Tested in quiz or exam

Examples of skill demonstrated, utilized, grade and tested are included as hyperlinked documents if provided by faculty member.

If additional information is needed, it will be gladly provided

Sincerely,

Elke 
BBA - Accounting - Implementation of Excel Skills - Fall 2003

\begin{tabular}{|c|c|}
\hline Course & Approved Skills for Implementation \\
\hline \multirow{9}{*}{$\begin{array}{l}\text { BISM } 2100 \text { - Business Information Systems } \\
\text { and Communication } \\
\text { Demonstrated Use by Faculty } \\
\text { BISM } 2100 \\
\text { All Faculty: Skills } 1-25 \text { as shown in } \\
\text { compilation are demonstrated through Excel } \\
\text { Practicum and objectives measured through } \\
\text { ProForma Case. } \\
\text { (D, U, G and T) }\end{array}$} & 1. $\quad$ Entering Data \\
\hline & 2. Click and Drag Copy \\
\hline & 3. Dates and Time \\
\hline & 4. Workbook Management \\
\hline & 5. Format Rows and Columns \\
\hline & 6. Format Cells \\
\hline & 7. Hidden Rows and Columns \\
\hline & 8. $\quad$ Inserting Text Boxes and Hyperlinks \\
\hline & 9. Inserting Comment Boxes \\
\hline \multirow{16}{*}{$\begin{array}{l}\text { Excel Assignment and Criteria } \\
\text { Case Background } \\
\text { Base Template }\end{array}$} & 10. Creating Charts, Bar, Line and Pie \\
\hline & 11. Formatting Charts, Axis and Legends \\
\hline & $\begin{array}{l}\text { 12. Importing and Exporting Charts, Word, PPT and } \\
\text { Access }\end{array}$ \\
\hline & 13. Capturing Data Ranges \\
\hline & 14. Copying and Filling In Data Ranges \\
\hline & 15. Formula Basics Employing,,$+- /, *$ and ${ }^{\wedge}$ \\
\hline & 16. Advanced Formula Operators \\
\hline & 17. Cell Reference Formulas \\
\hline & 18. Moving and Copying a Formula \\
\hline & 19. Absolute Cell References \\
\hline & 20. PMT Function \\
\hline & 21. PV and FV Function \\
\hline & 22. Using Templates \\
\hline & 23. Creating Professional Multi Page, Multi Sheet Reports \\
\hline & 24. Add In Tool - Data Analysis \\
\hline & 25. Comparison Calculator Operator (IF) \\
\hline \multirow{2}{*}{$\begin{array}{l}\text { ACCT } 2100-\text { Introduction to Financial } \\
\text { Accounting }\end{array}$} & 26. Create amortization tables: bonds, long term debt \\
\hline & $\begin{array}{l}\text { 27. Create depreciation schedules: straight line, double } \\
\text { declining balance, units of production or use }\end{array}$ \\
\hline $\begin{array}{l}\text { ACCT } 2200 \text { - Introduction to Managerial } \\
\text { Accounting }\end{array}$ & 28. Create budget worksheets: cash, master, flexible \\
\hline \multirow[t]{3}{*}{$\begin{array}{l}\text { ACCT } 3100-\text { Intermediate } \text { Financial } \\
\text { Accounting and Auditing }\end{array}$} & $\begin{array}{l}\text { 29. Create working trial balances and link adjusting } \\
\text { entries: unadjusted TB, adjustments, adjusted TB } \\
\text { accrual TB, conversion adjustments and cash flows }\end{array}$ \\
\hline & $\begin{array}{l}\text { 30. Create amortization tables: Bonds, long-term debt and } \\
\text { leases }\end{array}$ \\
\hline & $\begin{array}{l}\text { 31. Create depreciation schedules: straight line, Double } \\
\text { declining balance and units of production or use }\end{array}$ \\
\hline \multirow[t]{2}{*}{$\begin{array}{l}\text { ACCT 4100 }- \text { Advanced } \\
\text { Accounting }\end{array}$} & $\begin{array}{l}\text { 32. Create complex amortization tables: bonds, long-term } \\
\text { debt and leases }\end{array}$ \\
\hline & $\begin{array}{l}\text { 33. Create complex analytical worksheets: horizontal and } \\
\text { vertical analysis, ratio analysis }\end{array}$ \\
\hline \multirow[t]{2}{*}{ ACCT 4150 - Auditing and Assurance } & $\begin{array}{l}\text { 34. Create complex analytical worksheets: horizontal and } \\
\text { vertical analysis, ratio analysis }\end{array}$ \\
\hline & $\begin{array}{l}\text { 35. Create working trial balances and link adjusting } \\
\text { entries: unadjusted TB, adjustments, adjusted TB }\end{array}$ \\
\hline \multirow[t]{2}{*}{$\begin{array}{l}\text { ACCT 4200 }- \text { Advanced Managerial } \\
\text { Accounting }\end{array}$} & $\begin{array}{l}\text { 36. Create complex budget worksheets: cash, master and } \\
\text { flexible }\end{array}$ \\
\hline & 37. Variance analysis \\
\hline
\end{tabular}




\begin{tabular}{|l|l|}
\hline $\begin{array}{l}\text { ACCT 4600 - Governmental and Non-Profit } \\
\text { Accounting }\end{array}$ & $\begin{array}{l}\text { 38. Create working trial balances and link adjusting } \\
\text { entries: fund statements, conversion adjustments, } \\
\text { entity-wide }\end{array}$ \\
\hline ACCT 4700 - Business Valuation & $\begin{array}{l}\text { 39. Function Utilization: } \\
\text { 40. All time-value-of-money and capital budgeting } \\
\text { functionality, }\end{array}$ \\
& $\begin{array}{l}\text { 41. Univariate and multivariate statistical functions as they } \\
\text { apply to cost estimation - multiple regression }\end{array}$ \\
42. Logical functions and functions that manipulate multi- \\
column/row data for improved customer visualization \\
43. Develop multiple-time period, multiple-sheet budgets \\
and pro forma reports which contain \\
interdependencies: \\
44. Key field identification \\
45. Yield executive level reports \\
46. Sensitivity analysis in scenario construction
\end{tabular}

\section{Appendix F:}

Information and Presentation Technology Proposal For BISM 2100

Course Structure:

- $\quad$ System and software skills comprise 35\% of the BISM 2100 course content. With emphasis being placed in integrating technology in the curriculum, skills training and lab availability are becoming critical. If there is one continual complaint about BISM 2100 it is the inability to provide lab space for large classes. BISM 2100 sections, with average student average enrollment of over 100, are currently utilizing a wireless laptop cart for instruction. Laptops have been utilized as a viable solution, but the current number of registered students mandates a 3 student shared laptop environment and existing electronic classrooms seat only 40 students

- $\quad$ Business communication skills comprise $35 \%$ of the EBIZ 2100 course content. With assurance of learning goals in place, special emphasis is being placed on professional presentation and delivery skills. Students are currently required to present a formal report in a team environment. With an average class size of 100 students, in class presentations are burdensome, but necessary

Proposal:

- Convert classroom into a 120 seat electronic classroom with digital video recording equipment and projection control and editing room. Replace existing desktop to house flat screen monitor (hide-away) for full standard classroom utilization.

Provides:

- $\quad$ One-to-One ratio student to desktop

- Ideal environment for systems and software learning

- $\quad$ Maintains efficacy for standard classroom environment

- $\quad$ Encourages non BISM faculty to increase use of technology in large enrollment classes

- $\quad$ Students are direct recipients of BISM 2100 student fee

- $\quad$ Coles College increases technology assets with state of the art classroom

- $\quad$ Classroom Presentation Stage - Simulated Presentation Environment

- $\quad$ Recording equipment provides uploadable video files for submission of deliverables onto WebCT server 
- $\quad$ Students exposed to presentation technology

- Converts three days of in-class presentations to one day of developmental review

- $\quad$ Opportunity for students to practice, self evaluate and retain digital presentation file

- $\quad$ Strong tie-in to Assurance of Learning Goals and AACSB re-accreditation

- Leverages e-portfolio stratagem 


\section{Appendix E - Recruiter Microsoft Excel Worksheet}

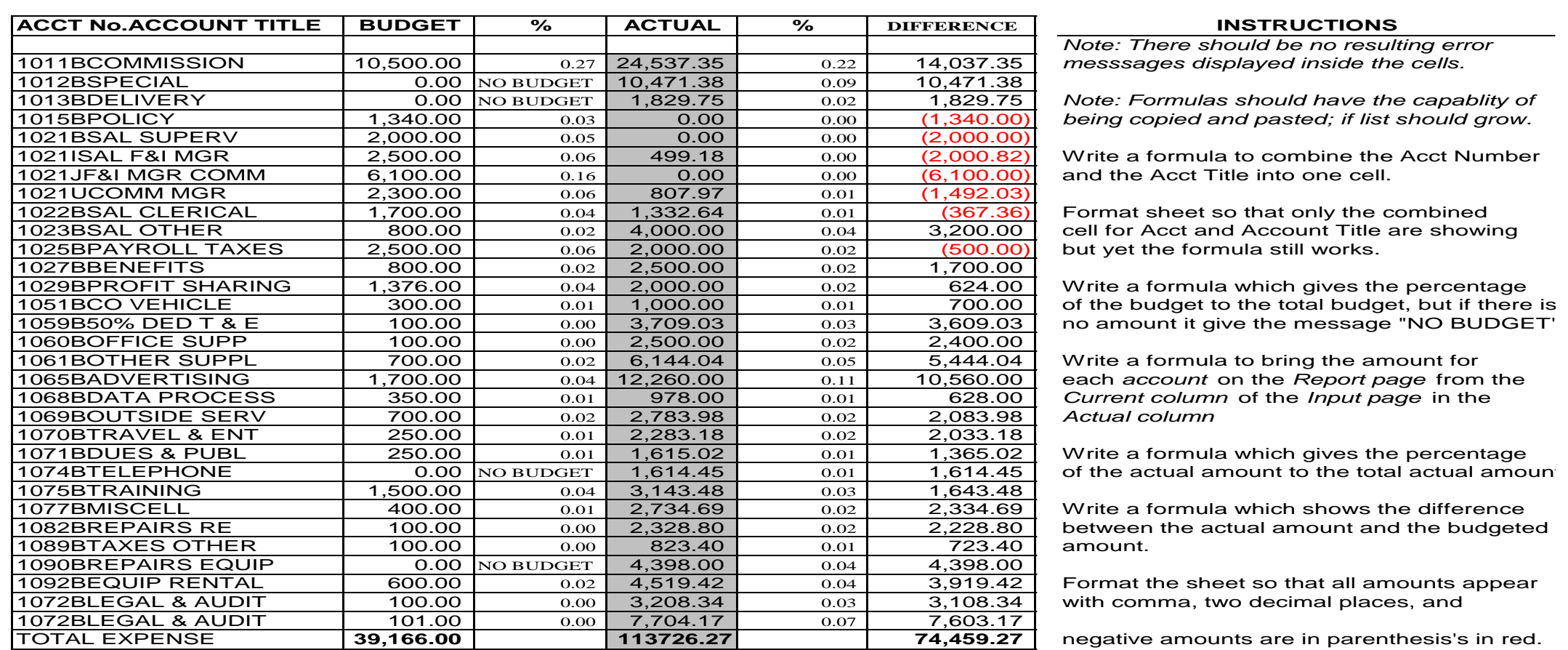


College Teaching \& Learning Conference

Walt Disney World, Florida, 2004 